any given case it must be shown that the cnzyme is in solution in the cell sap and not held in combination by the protoplasm.

UNIV. OF ARIZONA AGR. EXP. STA.,

TUCSON, ARIZONA.

\title{
NOTE ON THE DYER METHOD FOR THE DETERMINATION OF PLANT FOOD IN SOILS. ${ }^{1}$
}

BY FRANK 'T. SHUTT AND A. 'l'. CHARRON

Received March 24 , Igos.

During the past twenty years or so the problem of soil fertility has received much attention from chemists, physicists and biologists, and as a result there is to-day a clearer understanding as to what constitutes productiveness in a soil-its several factors and their relative importancethan there was a quarter of a century ago. We did not then recognize that the chemical data formed but one factor in soil diagnosis; that texture, moisture-holding capacity, bacterial life, drainage, precipitation, etc., must all be considered before drawing any conclusion as to a soil's probable productiveness. It was this neglect that caused doubt on all sides to be entertained as to the practical value of soil analysis, and indeed the agricultural chemist himself had well-nigh abandoned all hope of being able to interpret his own data for the benefit of the farmer. Though we are yet far from having soil diagnosis on a thoroughly satisfactory basis, a distinct advance has been made and the writers feel that one of the most prominent and valuable features of this diagnosis lies in the cletermination and recognition of the soil's store of more or less available plant food.

In so far as the soil's crop-producing power or the need of special fertilization can be determined by chemical means, the estimation of the plant food present in a condition more or less available for crop use must be a matter of considerable importance. The stores of insoluble, inert plant food, no matter how large, can be of but little value to the growing crop; it is rather those small percentages of potash, phosphoric acid, etc., that are at once capable of being utilized by plants that serve to measure the soil's immediate ability to sustain vegetable life. In these two classes we have represented what might be termed latent and potential fertility, though, of course, no strong line of demarkation can be drawn between them-the former being always converted into the latter, gradually but with varying rapidity, according to a number of conditions which we need not now discuss.

In I 894 Dr. Bernard Dyer, working on soils from the Rothamsted Experiment Station, the history of which as regards manuring and crop yields was well known, proposed the use of a 1 per cent. solution of citric acid as a solvent for the available phosphoric acid and potash.

${ }^{1}$ Read at the Chicago meeting of the American Chemical Society. 
His analytical data were well in accord with the field results and from the percentages obtained he was able to establish minimum and maximum limits regarding the necessity and non-necessity of phosphatic and potassic fertilizers. Further, he found that the sap of the rootlets of a number of farm plants had an average acidity approximately equivalent to that of I per cent. citric acid solution, thereby in a large measure confirming the correctness of his deductions respecting the value of the solvent proposed. ${ }^{1}$

Since that date, various solvents have been proposed, more especially in the United States. Several of these were experimented with in the laboratories of the Dominion Experimental Farms, Ottawa, but as they appeared to lack that evidence which had been brought forward to support the Dyer method, it has been the latter process that has always been employed in our official soil investigations. Dyer's limits have not been found to answer invariably, but this is only what might have been expected; the general nature of the soil must be taken into account, its geological origin and the climatic conditions of the district considered. On the whole, however, the method and proposed limits have proved very satisfactory. Possibly it is only a tentative method, but the fact remains that as data accumulate from workers in different parts of the world, its claims to represent the amounts of more or less readily assimilable mineral plant food in the soil receive corroboration.

Within the past two months the writers, in working on certain virgin prairie soils from the Northwestern provinces of the Dominion, have thought it desirable to ascertain how far the results might be affected by certain modifications of the original method as described by Dyer. These modifications were in the reduction of the time during which the solvent was in contact with the soil and in the reduction of the volume of solvent used per unit of air-dried soil, to obviate the necessity of evaporating large volumes of solution. Dyer's method calls for an extraction period of seven days, during the first six of which the mixture is kept constantly agitated, I000 cc. of solvent being used per Ioo grams of soil.

The soil sample was of a composite character, made up of 8 samples collected (at Tisdale, Sask.) on as many dates between June $15^{\text {th }}$ and October 20, 1907. It represented the native prairie soil to a depth of 8 inches. The soil had been "broken" in 1906, and this season (1907) bore a crop of wheat. It might be described as a rich, black loam in which sand predominated and typical of large areas in the Canadian Northwestern wheat belt. Analysis showed it to contain large percentages of semi-decayed vegetable matter and nitrogen, a characteristic feature of these prairie soils.

The analysis of the air-dried soil, according to the method of the A. 'J. Chem. Soc., 65, in 5-167 (1894). 
O. A. C., using I.115 sp. gr. hychrochloric acid as the solvent, afforded the following data:

\begin{tabular}{|c|c|}
\hline Moisture ........... & $\begin{array}{c}\text { Per cent. } \\
0.26\end{array}$ \\
\hline 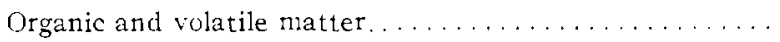 & $1.3 \cdot 34$ \\
\hline Insoluble matter, clay, sand, etc $\ldots \ldots \ldots \ldots \ldots \ldots \ldots$ & $68 .+9$ \\
\hline 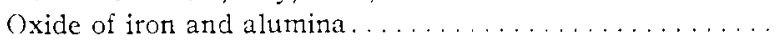 & 8.68 \\
\hline 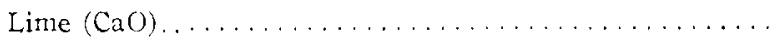 & I. of \\
\hline 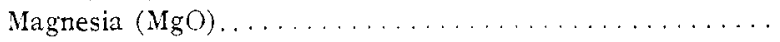 & 0.86 \\
\hline 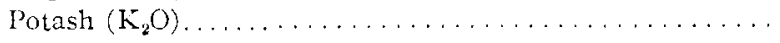 & 0.58 \\
\hline 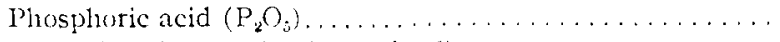 & 0.19 \\
\hline \multirow[t]{2}{*}{ 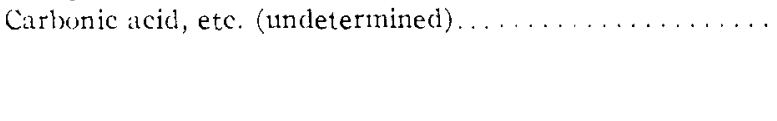 } & 0.56 \\
\hline & 100.00 \\
\hline Nitroge & \\
\hline
\end{tabular}

From these results we may conclude that as regards the stores of latent plant food, the soil is one very well supplied with nitrogen and potash; that phosphoric acid is present in fir amounts and that lime exists in quantitics sufficient for crop needs.

In the subjoined tabular statement the results obtained by the modifications of the Dyer process already referred to, are presented, the percentages of lime being given in addition to those of phosphoric acid and potash. All the data are averages from at least two closely concordant determinations:

INFLCENCE OF 'Time OF Digestion.

(Solvent: $1 \%$ Citric Acid Solution.)

\begin{tabular}{|c|c|c|c|}
\hline & $\begin{array}{c}\text { Phosphoric acid } \\
\left(\mathrm{P}_{2} \mathrm{O}_{5}\right) \\
\text { Percent. }\end{array}$ & $\begin{array}{l}\text { Potash } \\
\left(\mathbf{K}_{2} \mathrm{O}\right) \\
\text { Per cert. }\end{array}$ & $\begin{array}{l}\text { Lime } \\
\text { (CaO) } \\
\text { Per cent. }\end{array}$ \\
\hline 100 grams soil in $1000 \mathrm{cc} .7$ days. & 0.02287 & 0.03818 & 0.5320 \\
\hline roo grans soil in rooo cc. 5 hours.... & 0.01807 & 0.03958 & 0.5210 \\
\hline 100 grams soil in $500 \mathrm{cc} .7$ days..... & 0.01999 & 0.03 .35 .5 & 0.2718 \\
\hline IoO grams soil in $500 \mathrm{ce}, 5$ hours. & 0.01500 & 0.03089 & 0.2285 \\
\hline
\end{tabular}

Comparing first the data from the analyses made when using $1000 \mathrm{cc}$. of the solvent, it will be noticed that reducing the period of digestion from 7 days to 5 hours materially decreased the amount of phosphoric acid dissolved, but did not similarly affect the potash--the percentages of the latter being practically identical for both periods. The lime falls off but slightly with the shorter digestion.

Employing $500 \mathrm{cc}$. as the volume of solvent, the phosphoric acid percentages present practically the same differences as those already notedin other words, slightly higher amounts were obtained from the longer digestion. Five hours' digestion gave a somewhat lower percentage of potash than 7 clays, but the difference is almost within the limit of experimental error. The lime dissolved is markedly less for the shorter period. 
INFLUENCE OF VOLUME OF SOLVENT.

(Solvent: I \% Citric Acid Solution.)

$\begin{array}{ccc}\text { Phosphoric acid } & \text { Potash } & \text { Lime } \\ \left(\mathrm{P}_{2} \mathrm{O}_{5}\right), & \left(\mathrm{K}_{2} \mathrm{O}\right) . & (\mathrm{CaO}) . \\ \text { Per cent. } & \text { Per cent. } & \text { Percent. }\end{array}$

Ioo grams soil in 1000 cc. 7 days..... 0.02287

$0.03818 \quad 0.5320$

I00 grams soil in $500 \mathrm{cc} .7$ days...... 0.01999

0.03355

0.2718

100 grams soil in 1000 cc. 5 hours.... 0.01807

0.03958

0.5210

100 grams soil in 500 cc. 5 hours..... 0.01599

0.03089

0.2285

In this table are given the same data as in the preceding, but they are arranged to more readily show the influence of the volume of solvent. No detailed discussion of these data is necessary; a glance at the figures is sufficient to make apparent the only conclusion that can be reached, viz., that reducing the volume of solvent used, materially decreases the percentages of phosphoric acid and potash obtained. In the case of lime, the smaller volume extracted but one-half that taken out by the larger volume. Clearly the influence of volume of solvent is decidedly greater than that of the period of extraction.

No doubt soils of a different character would not yield results that would fall exactly into line with those here recorded, that is, as to the effect of varying the period of extraction and the volume of the solvent on the amount of mineral matter dissolved, but the general trend would, we believe, be the same. It seems highly desirable that further data on this important question of available plant food should be obtained from widely different points and correlated with the field results. These analytical data should be, as far as is practicable, strictly comparable, and to this end it is evidently necessary that the details of the process as regards period of extraction and volume of solvent, should be carried out alike by all workers. There seems to be every reason for adherence, in these respects, to the time and volume as given by Dr. Dyer in his original account of the process.

DOMINION RXPERIMENTAL FARM,

OtTawa, Canada.

\section{SOME OBSERVATIONS ON THE ASSAY OF TELLURIDE ORES.}

BY GEORGE BORROWMAN.

Received April 4, Igo8.

Much has been written concerning the assaying of telluride gold and silver ores, yet the literature affords striking contradictions as well as statements unsupported by experimental data. However, there seems to be agreement in the opinion that tellurium is the cause of serious irregularities. Mr. A. I. Davis, in Tech. Quart., Vol. XII, sums up the situation as follows: "As to the percentage of loss sustained in work, whether by scorification or crucible method, many experiments carried out upon the foregoing lines indicate to me that nothing definite can be 